\title{
Phase Stability and Grain Growth in an Ag/Bi-2223 Composite Conductor Prepared Using Fine-Grained Bi-2223 as a Precursor*
}

\author{
N.N. Merchant, D.J. Miller, and V. A. Maroni \\ Argonne National Laboratory \\ Argonne, IL 60439 \\ R.D. Parrella, Q. Li, M.W. Rupich, W.L. Carter, and G.N. Riley, Jr. \\ American Superconductor Corporation \\ Westborough, MA 01581
}

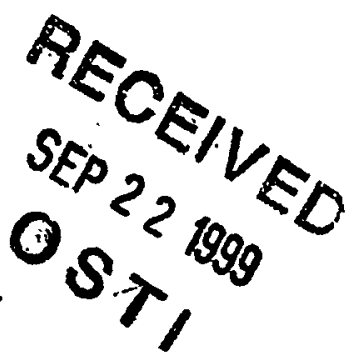

Prepared for presentation at the 1998 Applied Superconductivity Conference,

September 13-18, 1998, Palm Desert, CA

The submitted manuscript has been created by the

University of Chicago as Operator of Argonne

National Laboratory ("Argonne") under Contract No.

W-31-109-ENG-38 with the U.S. Department of

Energy. The U.S. Government retains for itself, and

others acting on its behalf, a paid-up, nonexclusive,

irrevocable worldwide license in said article to

reproduce, prepare derivative works, distribute copies

to the public, and perform publicly and display

publicly, by or on behalf of the Government.

*Work at Argonne National Laboratory was sponsored by the U. S. Department of Energy, Energy Efficiency and Renewable Energy, as part of a DOE program to develop electric power technology, under Contract W-31-109-ENG-38. 


\section{DISCLAIMER}

This report was prepared as an account of work sponsored by an agency of the United States Government. Neither the United States Government nor any agency thereof, nor any of their employees, make any warranty, express or implied, or assumes any legal liability or responsibility for the accuracy, completeness, or usefulness of any information, apparatus, product, or process disciosed, or represents that its use would not infringe privately owned rights. Reference herein to any specific commercial product, process, or service by trade name, trademark, manufacturer, or otherwise does not necessarily constitute or imply its endorsement, recommendation, or favoring by the United States Government or any agency thereof. The views and opinions of authors expressed herein do not necessarily state or reflect those of the United States Government or any agency thereof. 


\section{DISCLAIMER}

Portions of this document may be illegible in electronic image products. Images are produced from the best available original document. 


\title{
Phase Stability and Grain Growth in an Ag/Bi-2223 Composite Conductor Prepared Using Fine-Grained Bi-2223 as a Precursor
}

\author{
N.N. Merchant, D.J. Miller, and V.A. Maroni, \\ Argonne National Laboratory, Argonne, IL 60439
}

R.D. Parrella, Q. Li, M.W. Rupich, W.L. Carter, and G.N. Riley, Jr. American Superconductor Corporation, Westborough, MA 01581

\begin{abstract}
We have investigated the stability and microstructural transformability of the $B \mathrm{i}-\mathbf{2 2 2 3}$ phase in a silver-sheathed monofilament composite tape fabricated using fine-grained $\mathrm{Bi}_{1.7} \mathrm{~Pb}_{0.3} \mathrm{Sr}_{1.9} \mathrm{Ca}_{2.0}$ $\mathrm{Cu}_{3,0} \mathrm{O}_{\text {y }}(\mathrm{Bi}-2223)$ as the precursor powder. The fully formed Bi-2223 precursor was prepared using established procedures. The purpose of this study was to explore the prospects for growing textured, large-grain-size Bi-2223 from the fine-grained precursor by process parameter perturbations. These perturbations included thermal ramp up variations, programmed heat treatment temperature and oxygen pressure fluctuations, and parameter manipulations during cool-down. Our results show that the types of heat treatments used in conventional oxidepowder-in-tube (OPIT) processing do not facilitate Bi-2223 grain growth when the precursor powder is preconverted Bi-2223. We also observed that the Bi-2223 partially. decomposed during conventional thermal ramp-up in 0.075 atm $\mathrm{O}_{2}$, but that this decomposition can be inhibited by ramping up in a reduced oxygen pressure. A pathway was found for back-reacting the fine-grained $\mathrm{Bi}-2223$ (to $\mathrm{Bi}$ 2212, Bi-2201 and nonsuperconducting secondary phases), then reforming large-grained $\mathrm{Bi}-2223$ in a colony microstructure having some distinct differences from that produced during conventional OPIT processing.
\end{abstract}

\section{INTRODUCTION}

The silver-sheathed $(\mathrm{Bi}, \mathrm{Pb})_{2} \mathrm{Sr}_{2} \mathrm{Ca}_{2}-$ $\mathrm{Cu}_{3} \mathrm{O}_{\mathrm{y}}(\mathrm{Ag} / \mathrm{Bi}-2223)$ composite conductor in long length multifilament form stands today as the state-of-the-art for practical utilization of high-critical-temperature $\left(\right.$ high $-\mathrm{T}_{\mathrm{c}}$ ) superconductivity in electric

Manuscript received September 14, 1998.

Work performed at Argonne National Laboratory was sponsored by the U.S. Department of Energy, Energy Efficiency and Renewable Energy as part of a DOE program to develop electric power technology, under Contract No. W-31-109-ENG-38. power applications [1-5]. Achieving the levels of current carrying capacity in the $\mathrm{Ag} / \mathrm{Bi}-2223$ composite conductor required for such applications has spurred a substantial development effort to optimize processing strategies and to refine processing parameters [6-10]. In order to obtain high $\mathrm{J}_{\mathrm{c}}$ and good in-field properties i $\mathrm{n}$ these materials, it is essential to have largegrained, textured microstructures with extremely fine secondary phases that can act as pinning centers [11]. In two prior studies, Duo et al. [12] and Parrell et al. [13] also investigated the $\mathrm{Bi}-2223$ decompositionreformation route. Their work showed that such treatments can influence the microstructure, phase chemistry, and performance properties $\left(\mathrm{J}_{\mathrm{c}}\right.$ and flux pinning) of $\mathrm{Ag} / \mathrm{Bi}-2223$ composites. However, in both cases [12,13], the starting phase assemblage in the tape was $\mathrm{Bi}-2212$ and secondary phases to give an overall $\mathrm{Bi}-2223$ stoichiometry. In our work, the starting phase assemblage is fine-grained $95 \%$ pure $\mathrm{Bi}-2223$ with minor amounts of $\mathrm{Bi}-2212$ and secondary phases. We have found a pathway for back reacting this fine-grained $\mathrm{Bi}-2223$ (to $\mathrm{Bi}-2212, \mathrm{Bi}-2201$ and secondary phases), then reforming large-grained $\mathrm{Bi}-2223$ in a colony microstructure, distinct in some respects from that produced by conventional OPIT processing.

\section{EXPERIMENTAL PROCEDURE}

The monofilamentary OPIT Ag/Bi-2223 composite tapes employed in this research were prepared by methods described in previous publications [6-8]. The precursor powder used in this study had the nominal composition $\mathrm{Bi}_{1.7} \mathrm{~Pb}_{0.3} \mathrm{Sr}_{1.9} \mathrm{Ca}_{2.0} \mathrm{Cu}_{3.0} \mathrm{O}_{\mathrm{y}}$ and was composed of fine-grained $\mathrm{Bi}-2223$ mixed with 
small amounts of Bi-2212 and alkaline earth cuprates. The precursor powder was prepared by a freeze-dry process.

Short samples (ca. 1 inch long) cut from a monofilament tape were either ramp heated $\left(10^{\circ} \mathrm{C} / \mathrm{min}\right.$ up to $800^{\circ} \mathrm{C}$ and $2^{\circ} \mathrm{C} / \mathrm{min}$ to $\left.825^{\circ} \mathrm{C}\right)$ or immersion heated $\left(100^{\circ} \mathrm{C} / \mathrm{min}\right)$ to an initial processing temperature of $825^{\circ} \mathrm{C}$ i n a 3-zone resistively heated furnace under a $\mathrm{pO}_{2}$ of either 0.075 atm or 0.046 atm. Temperature excursions either downward to $780^{\circ} \mathrm{C}$ for 30 minutes or upward to $855^{\circ} \mathrm{C}$ for 20 minutes were programmed into the anneal cycle after an initial 3000 minute hold at $825^{\circ} \mathrm{C}$ in 0.075 atm $\mathrm{O}_{2} . \mathrm{PO}_{2}$ variations to $0.002,0.02$ and 0.046 atm during annealing at $825^{\circ} \mathrm{C}$ were also studied. Samples were either quenched or furnace cooled after each heat treatment [14]. They were characterized using scanning electron microscopy (SEM), energy dispersive $x$-ray analysis (EDS), and $x$-ray diffraction (XRD) in the manner described by Luo et al. [14] and Merchant et al. [15].

\section{RESULTS AND DISCUSSION}

Figure 1 shows two of the types of heat treatment cycles used in the decompositionreformation studies reported here. XRD measurements on samples annealed under the cycle depicted in Fig.1a but quenched after 0 minutes at $825^{\circ} \mathrm{C}$ in 0.075 atm $\mathrm{O}_{2}$ revealed that as much as $50 \%$ of the $\mathrm{Bi}-2223$ phase decomposed to $\mathrm{Bi}-2212$ and secondary phases during the ramp-up to $825^{\circ} \mathrm{C}$. A similar decomposition of the Bi-2223 phase was also observed when the samples were immersion heated. However, in subsequent studies we found that this decomposition, could be fully arrested by ramp heating the sample to $825^{\circ} \mathrm{C}$ under a $\mathrm{pO}_{2}$ of $0.002 \mathrm{~atm}$. This can be mainly attributed to the fact that the phase stability boundaries of $\mathrm{Bi}-2223$ a re crossed during-ramp up in 0.075 atm $\mathrm{O}_{2}$, but are not in the lower $\mathrm{pO}_{2}$ of 0.002 atm [15].

Figure 2 shows an SEM micrograph of the transverse cross section of a sample annealed for 6000 minutes in 0.075 atm $\mathrm{O}_{2}$ at $825^{\circ} \mathrm{C}$ and furnace cooled. The micrograph shows that layered phase grain growth is essentially nonexistent and that transverse cracks appear with regularity. This, we believe, is due to the fact that during normal OPIT processing of a tape that has $\mathrm{Bi}-2223$ as the major phase to begin with, no liquid phase is formed during heat treatment to facilitate grain growth. Also, cracks that may have formed during the deformation processing before the annealing cannot be healed due to the persistant absence of liquid phase.

Figure 3 shows an SEM micrograph of a sample annealed using the cycle shown in Fig. 1b, which features a 20 minute excursion to $855^{\circ} \mathrm{C}$ followed by a 3000 minute recovery treatment at $825^{\circ} \mathrm{C}$. It is evident from the micrograph that layered phase grain growth does occur under these conditions. Also, no cracks are visible in the sample, indicating that all cracks formed during the deformation processing are healed, quite possible due to the presence of a liquid phase. XRD showed that the sample is $80 \% \mathrm{Bi}$ $2223,16 \% \mathrm{Bi}-2212$, and ca. $4 \% \mathrm{Bi}-2201$. It is
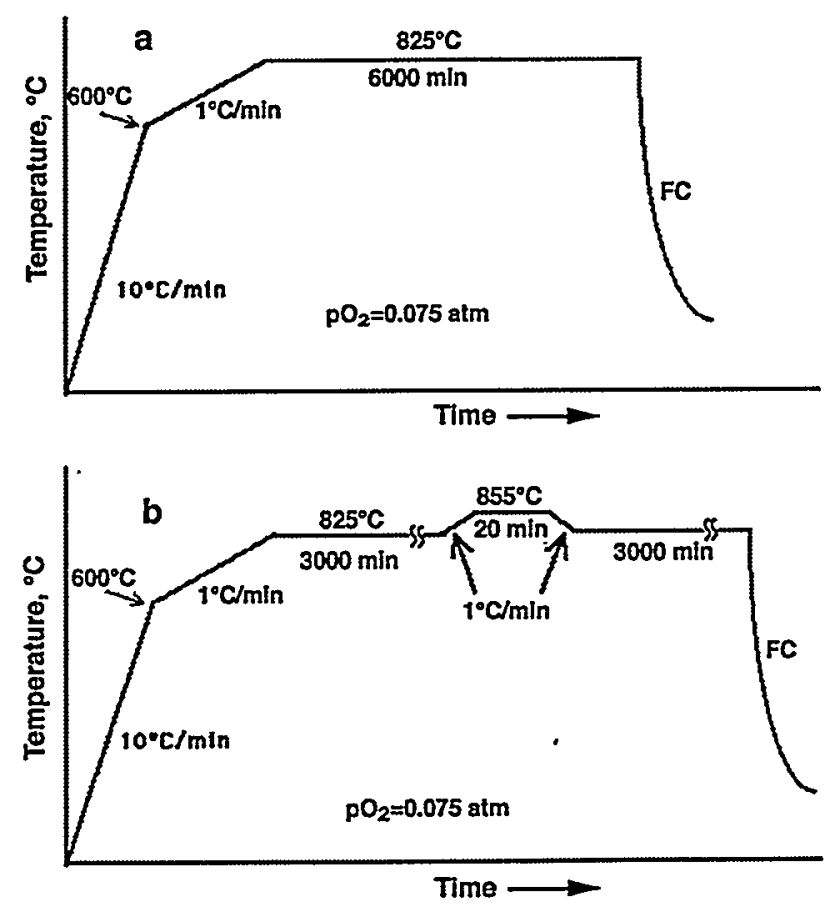

Fig. 1. Heat treatment cycles for $\mathrm{Ag} / \mathrm{Bi}-2223$ decomposition/reformation tests: (a) blank run and (b) partial melt simulation procedure. 
not clear that annealing the sample for a time longer than 3000 minutes after the

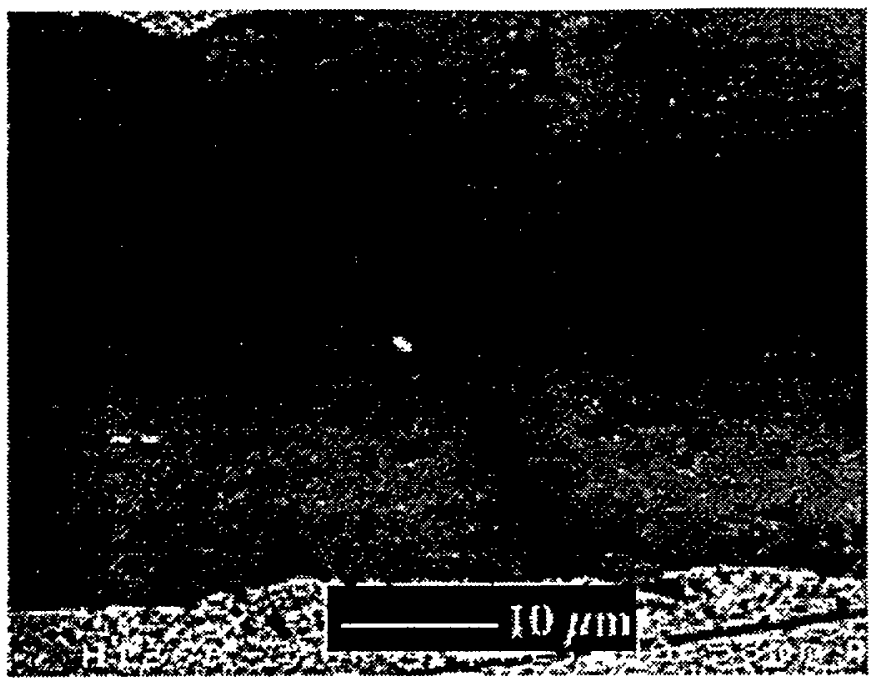

Fig. 2. SEM micrograph in backscatter mode of transverse section of monofilament sample annealed for 6000 minutes at $825^{\circ} \mathrm{C}$ i n $0.075 \mathrm{~atm} \mathrm{O}_{2}$.

high temperature excursion will necessarily produce complete reformation of the Bi-2223. Alternatively, the excursion temperature and/or time may have to be shortened to limit the decomposition of $\mathrm{Bi}-2223$. It is also noteworthy that the nonsuperconducting secondary phases are really quite small after this decomposition-reformation treatment.

Figure 4 shows a TEM micrograph of a sample that was subjected to the cycle in Fig. 1b. This micrograph highlights a unique microstructural effect of the decompositionreformation treatment, i.e., the occurance of large adjacent $\mathrm{Bi}-2223 / \mathrm{Bi}-2212 \mathrm{grain}$ colonies near the Ag/superconductor interface that have (001) orientation.

Our efforts during this study to investigate low temperature dips in the anneal cycle e.g., $825^{\circ} \mathrm{C}$ for 3000 minutes $/ 780^{\circ} \mathrm{C}$ for 30 minutes $/ 825^{\circ} \mathrm{C}$ for 3000 minutes in 0.075 atm $\mathrm{O}_{2}$ had no discernable impact on the Bi-2223 microstructure. Also, attempts to use longer excursion periods (e.g., $855^{\circ} \mathrm{C}$ for up to 920 minutes) resulted in substantial decomposition of the $\mathrm{Bi}-2223$ layered phase $(80 \%+)$ with concomitant large secondary phases that could not be reformed by post annealing at $825^{\circ} \mathrm{C}$ in 0.075 atm $\mathrm{O}_{2}$. Some efforts were also made to manipulate the microstructure via low $\mathrm{pO}_{2}$ anneal, (e.g., use of $0.02 \mathrm{~atm}$ and $0.002 \mathrm{~atm}$ $\mathrm{O}_{2}$ at $825^{\circ} \mathrm{C}$ ); how-

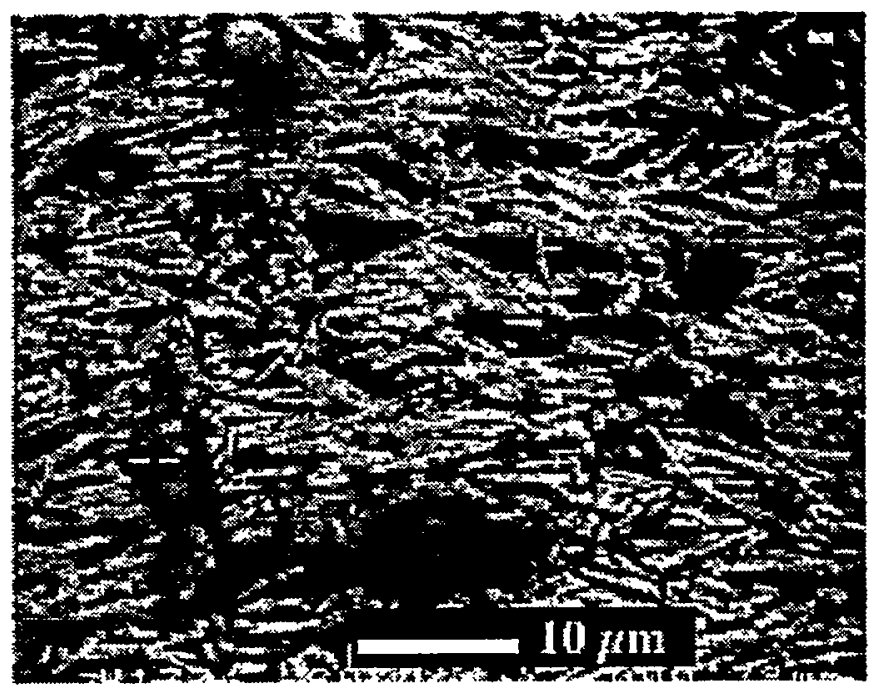

Fig 3. SEM micrograph in backscatter mode of transverse section of sample annealed using cycle shown in Fig. $1 b$.

ever, these manipulations led to results similar to the extended high temperature excursions, i.e., substantial decomposition of the Bi-2223 phase (over 80\%) that could not be recovered to any significant extent by post annealing.

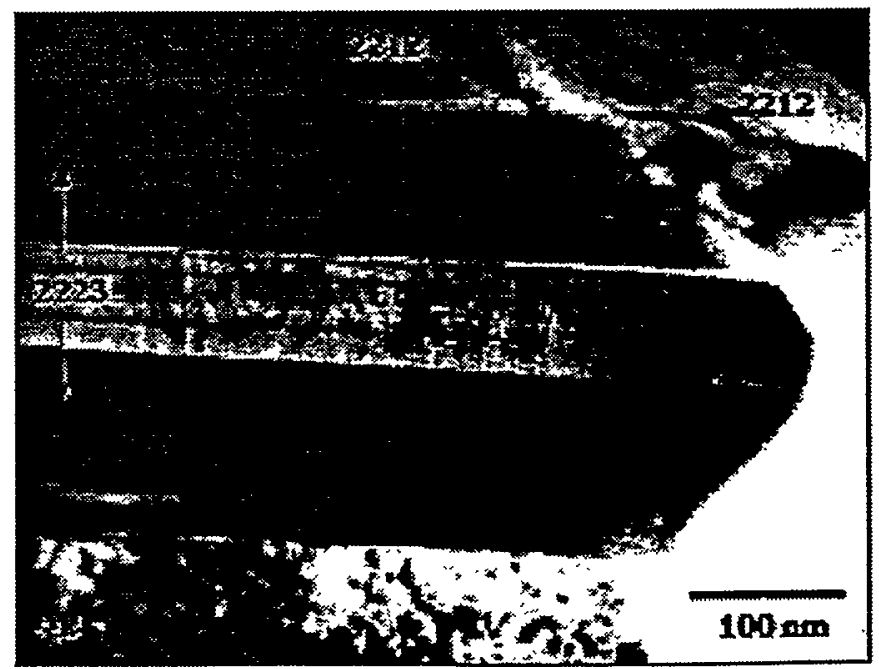

Fig. 4. TEM micrograph of sample subjected to $855^{\circ} \mathrm{C}$ excursion, showing large colonies of $\mathrm{Bi}-2223$ and $\mathrm{Bi}-2212$ grains. 


\section{CONCLUSIONS}

Preconverted $\mathrm{Bi}-2223$ in a silver sheath backreacts to $\mathrm{Bi}-2212$ plus secondary phases during ramp and immersion heating in $0.075 \mathrm{~atm} \mathrm{O}_{2}$. This decomposition can be arrested by use of $0.002 \mathrm{~atm} \mathrm{O}_{2}$ during ramp up. Extended heat treatment at $825^{\circ} \mathrm{C}$ in 0.075 atm $\mathrm{O}_{2}$ reforms nearly all of the Bi-2223 phase, but does not result in any significant grain growth. Intermittent temperature dipping to $780^{\circ} \mathrm{C}$ does not have any visible effect on the microstructure of the layered phase. Extended excursions at high temperature (to $855^{\circ} \mathrm{C}$ in 0.075 atm $\mathrm{O}_{2}$ ) and reduced $\mathrm{pO}_{2}$ anneal $\left(0.02\right.$ atm $\mathrm{O}_{2}$ and lower at $825^{\circ} \mathrm{C}$ ) led to melting/decomposition of the Bi-2223 phase that can be only partially reformed by annealing at $825^{\circ} \mathrm{C}$. Brief temperature excursions to $855^{\circ} \mathrm{C}(0$ to 20 minutes) followed by extended anneal at $825^{\circ} \mathrm{C}$ in $0.075 \mathrm{~atm} \mathrm{O}_{2}$ lead to layered phase grain growth, elimination of cracks and reduced secondary phases. This general type of treatment (decomposition/reformation) represents an interesting and potentially effective technique for improving Jc and flux pinning in Ag-clad Bi-2223 composite conductors.

\section{ACKNOWLEDGMENT}

The authors wish to recognize the valuable discussions held with members of the Wire Development Group led by American Superconductor, including D.C. Larbalestier, D.M. Kroeger, J.O. Willis, J.F. Bingert, and T.G. Holsinger.

\section{REFERENCES}

[1] A.P. Malozemoff, Q.Li, S. Flesher, $M^{2} S$ Conference, Beijing, China, Feb. 28 to March 3, 1997.

[2] T.P. Beales, C.M. Friend, L. LeBoy, M. Molgg, C. Dineen, D.M. Jacobson, S.R. Hall, M.R. Harrison, P.F. Hermann, A. Petibon, P. Carcino, L. Gherardi, P. Metra, G. Bogner, and H.-W. Neumller, Supercond. Sci. Technol. 8, p. 909, 1995.

[3] D.M. Buczek, LJ. Masur, P.K. Miles, F. Sivo, D. Marlowe, E.R. Podtburg, D.R. Parker, S.
Flescher, J.D. Scudiere, P. Metra, M. Nassi, M. Rahman, and D.W. Von Dollen, IEEE Transactions on Applied Superconductivity 7, p. 2196, 1997.

[4] K. Sato, Journal of Metals 47, p. 65, 1995.

[5] W.E. Brockenborough and A.P. Malozemoff, Journal of Metals 47, p. 59, 1995.

[6] W.L. Carter, G.N. Riley, Jr., A. Otto, D.R. Parker, C.J. Christopherson, L.J. Masur, and D. Buczek, IEEE Transactions on Applied Superconductivity, 5(2), p. 1145, 1995.

[7] M.J. Minot, D. Buczek, J.J. Gannon, P.K. Miles, and D.R. Parker, IEEE Transactions on Applied Superconductivity, 5(2), p. 1246, 1995.

[8] Q. Li, G.N. Riley, Jr., R.D. Pareeella, S. Flesher, M.W. Rupich, W.L. Carter, J.O. Willis, J.Y. Coulter, J.F. Bingert, V.K. Sikka, J.A. Parrell, and D.C. Larbalestier, IEEE Transactions on Applied Superconductivity 7, p. 2026, 1997.

[9] L.R. Motowidlo, G. Galonski, G. Ozeryansky, W. Zhang, E.E. Hellstrom, M. Sumption, and T. Collings, IEEE Transactions on Applied Superconductivity 5(2), p. 1162, 1995.

[10] A.Otto, L.J. Masur, C. Craven, D. Daly, E.R. Podtburg, and J. Screiber, IEEE Transactions on Applied Superconductivity 5(2), p. 1154, 1995.

[11] K. Sato, N. Shibuta, H. Mukai, T. Hikata, M. Euyama, and T. Kato, J. Appl. Phys. 70, p. 6484, 1991

[12] S.X. Duo, H.K. Liu, Y.C. Guo, and D.L. Shi, IEEE Transactions on Applied Superconductivity 3, p. 11, 1993.

[13] J.A. Parrell, Y. Feng, S.E. Dorris, and D.C. Larbalestier, J. Mater. Res. 11, p. 555, 1996.

[14] J.S. Luo, N. Merchant, E.J. EscorciaAparicio, V.A. Maroni, B.S. Tani, W.L. Carter, and G.N. Riley, J. Mater. Res 9, p. 3059, 1994.

[15] N. Merchant, J.S. Luo, V.A. Maroni, S.N. Sinha, G.N. Riley, Jr., W.L. Carter, Appl. Supercond. 2, p. 217, 1994. 